\title{
RISK OF MASSIVE BLOOD LOSS IN POSTPARTUM VAGINAL HEMATOMA
}

\author{
Novikova V. A. ${ }^{1}$, Aseeva E. V. ${ }^{1}$, Uglova N. D. ${ }^{2}$, Khorolsky V. A. ${ }^{1}$, \\ Filina K. V. ${ }^{1}$, Kazibekova F. Sh. ${ }^{1}$ \\ ${ }^{1}$ Kuban State Medical University, Krasnodar, Russian Federation \\ 2 Volgograd State Medical University, Russian Federation
}

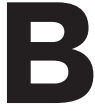

leeding is part of the "Big 5 " reasons behind maternal mortality, which includes sepsis, eclampsia, cephalopelvic disproportion, and "dangerous" abortion [9]. Acute massive blood loss implies here either the loss of over $1,000 \mathrm{ml}$ of blood or $15 \%$ of the blood circulation volume (BCV), or $1.5 \%$ of the body weight. A severe life-threatening hemorrhage is the loss of $100 \%$ BCV within 24 hours or $50 \%$ of BCV within 3 hours; it can also be blood loss at the rate of $150 \mathrm{ml} / \mathrm{min}$ or $1.5 \mathrm{ml} /(\mathrm{kg} / \mathrm{min}$ ) (in over $20 \mathrm{~min}$ ); or a single loss of $1,500-2,000 \mathrm{ml}$ of blood, or $25-35 \%$ of BCV $[1,7,9]$.

As of today there is a wide range of practices available to reduce perioperative blood loss, which is based on both surgical and anaesthesic methods for blood volume maintenance. These include operative techniques with minimal invasive surgery, possible temporary or permanent blockage of great vessels, embolization of arteries supplying blood to the operative field; thorough hemostasis during a surgery with minimized blood loss - tissue dissection employing advanced coagulation appliances: microwave coagulation scalpels, laser scalpels, argon plasma coagulators, electrocoagulators, use of local hemostatic agents; choice of anaesthesia; normovolemic and hypervolemic hemodilution; intraoperative monitoring of BCV and blood coagulation system using approved autotransfusions; creating conditions favoring oxygen delivery and its reduced

Novikova Vladislava, MD, PhD, Associate Professor of the Department of Obstetrics, Gynecology and Perinatology, Faculty for Advanced and Postgraduate Training of Specialists, Kuban State Medical Academy; tel.: +7(918)3506237; e-mail: vladislavan@mail.ru

Aseeva Evgenia, Postgraduate student of the Department of Obstetrics, Gynecology and Perinatology, Faculty for Advanced and Postgraduate Training of Specialists, Kuban State Medical Academy; tel.: 8(918)4828286, 8(926)0355777;

e-mail: aseeva.eva@mail.ru

Uglova Natalya, PhD, Assistant Professor of the Department of Obstetrics and Gynecology, Faculty for Advanced Training of Specialists, Volgograd State Medical University

Khorolsky Vadim, PhD, Assistant Professor of the Department of Obstetrics, Gynecology and Perinatology, Faculty for Advanced and Postgraduate Training of Specialists, Kuban State Medical Academy, obstetrician-gynecologist of the Centre for Perinatology of the Municipal Health Agency Hospital № 2

Filina Karina, Postgraduate student of the Department of Obstetrics, Gynecology and Perinatology, Faculty for Advanced and Postgraduate Training of Specialists, Kuban State Medical Academy tel.: 8(918)3506237; e-mail: vladislavan@mail.ru consumption in the tissues; use of blood substitutes; autologous blood reinfusion due to collection of shed blood from the surgical field, which allows rational use of the patient's blood; normothermia, etc. [7, 9].

Yet, at least 530,000 women all over the world pass away because of pregnancy and delivery; around 200,000 die because of blood loss [1]. The total rate of those dying all over the world through pregnancy or delivery is 1 woman per minute; as for obstetrical hemorrhage - 1 woman dies each three minutes. Of these cases $50 \%$ can be accounted for by hypotonia or atonia of the uterus in the postnatal period. Bleeding is part of the «Big 5 » reasons behind maternal mortality, which includes sepsis, eclampsia, cephalopelvic disproportion, and «dangerous» abortion [11].

The major risk factors of hemorrhage in the postpartum period are placental presentation; a prolonged third stage of labor; all or part of the placenta or membranes retention in the uterine cavity; preeclampsia; medial lateral episiotomy; a postpartum hemorrhage in the past medical history; multiple pregnancy; uterine inertia; a birth canal trauma; a big fetus; a prolonged labor; an operative vaginal delivery; medial episiotomy $[1,7,11]$. The specific feature about obstetrical hemorrhages is the risk of their massiveness and suddenness. Sometimes a hemorrhage may affect the fetus which requires urgent delivery without waiting for stable hemodynamic parameters. In case of gestosis with potential initial blood circulation volume deficit an acute massive blood loss of up to $1000 \mathrm{ml}$ may result in a hypovolemic shock $[7,9]$.

Quite a role in the development of postpartum hemorrhage with acute massive blood loss also play iatrogenic effects related to «obstetric aggression» through the delivery: non-motivated labor induction and augmentation, amniotomy with immature cervix uteri, and the employment of Christeller's method, which contributes to the birth canal traumatism [1].

However, acute massive blood loss may be due to hematomas developed as a result of vaginal blood vessels traumatism. The rate of the postpartum period complicated by hematomas comes up to $1: 1,000-1: 4,000$ of deliveries. $85-90 \%$ of the cases are complications of episiotomy. The proven risk factors for hematomas include instrumental vaginal delivery, first labor, preeclampsia, multiple 
pregnancy, big fetus, prolonged bearing-down stage of labor, vein disease [2, 10].

As far as acute massive blood loss is concerned, the threat can be seen in supralevator hematoma, which has no fibrous boundary and is developed in case of lesion to uterine arteries, the pudendal artery or the inferior bladder artery, and expands onto the broad ligament, the presacral space and the retroperitoneal space [2, 10].

The specific point of the infralevator hematoma is that it is restricted from above with the levator ani muscle, medially - with the central tendon of perineum, laterally - with the Colles fascia and the broad ligament. In case of this localization hematoma may spread onto the ischiorectal fossa. Infralevator hematomas develop in case of trauma of the labia minora vessels, the vulva, the inferior bladder artery, the vaginal branches of the uterine arteries or the inferior rectal artery branches. Nonoperative treatment is a possible option if we speak about hematomas below $3 \mathrm{~cm}$. In case of growing and massive hematomas prior to hematoma evacuation there is a need for BCV resuscitation. During a surgical revision of hematoma mandatory things are proper anesthetic management, good light, and assistance. The affected vessels need a ligature applied until a meticulous hemostasis, and a close dead space. Dynamic control is required as the risk of relapse remains extremely high [2].

The issue about postpartum hematomas is that there is a possibility of a vaginal varicose veins trauma without its mucous membrane lesion, lack of dramatic clinical symptoms under labor analgesia (continuous epidural analgesia (CEA)), analgesia after wound closure in the dissected or injured perineum tissues. The polymorphism and non-specificity of the clinical presentations in the varicose veins of the small pelvis may lead to gross diagnostic errors [3].

Vein disease of the small pelvis with the perineum and the vulva involved is found in $30 \%$ of pregnancies. The major reasons behind that include loss of tone and elasticity of the venous walls against increased female hormones, and large veins compression in the retroperitoneal space (in the vena cava inferior and the iliac veins) caused by the enlarged uterus [5].

Vein disease derives from non-differentiated connective tissue dysplasia (CTD) [6].

Organic and functional disorders in the small pelvis venous system in case of the small pelvis vein disease are described with progredient dilatation of the main venous collectors of the small pelvis (uterine, ovarian, internal iliac, and arcuate veins); progredient venous blood velocity reduction in the uterine veins; and microcirculatory disorders in the small pelvis. Undifferentiated forms of connective tissue dysplasia are among the causative factors of the small pelvis vein disease in women [8].

Given that, the issue of predictability and preventive measures for acute massive blood loss in obstetric care appears of special urgency.
The need for prediction of acute massive blood loss in obstetric care allows organ preservation treatment under hemorrhage, and is a serious preventive measure not against complications of the postpartum period alone yet also in relation to maternal morbidity and mortality reduction.

The purpose of this research is to evaluate the efficacy of the modern ultrasound diagnostics of postpartum vaginal hematoma in women suffering from varicose veins of the lower extremities.

Material and Methods. The reason behind this research is a case study of eight postpartum hematomas accompanied with acute massive blood loss $(1850 \pm 239.58 \mathrm{ml})$ detected in the maternity hospitals of Krasnodar and the adjacent areas within 2006-2009. An investigation into the major causes of the acute massive blood loss due to postpartum hematomas showed that in all cases hematomas developed with no vaginal mucous membrane defects; all the women had vein disease in different areas; all the women had had labor analgesia through continuous epidural analgesia (CEA).

In 2009-2011 a comprehensive study was conducted at the Perinatal Center of the Municipal Healthcare Institution City Hospital № 2 (Krasnodar Medical-Diagnostic Multi-profile Institution) involving 120 women with varicose veins of the lower extremities. The control group was 100 females with no varicose veins of the lower extremities. The comparison groups' members were around similar by their median age: $24.2 \pm 5.12 \mathrm{yrs}$; by weight: $74.03 \pm 11.25 \mathrm{~kg}$; by body weight gain in the current pregnancy: $15.61 \pm 4.88 \mathrm{~kg}$. In all women the pregnancies were unassisted. The gestational age in the comparison groups was $38.20 \pm 1.09$ weeks. $26(21.7 \%)$ women were expecting their first labor, while in 40 (78.3\%) cases the labors to come were repeated (in past obstetrics history of all women $2.94 \pm 2.53$ labors (from 2 to 8 )). In all the cases those were conservative and spontaneous labors. In the postpartum period ( 2 hours after the labor) the women had transperineal ultrasound study of the vagina and the perineum with the ultrasound scanner PHILLIPS HD-11.

Results and Discussion. An investigation into the varicose veins of the lower extremities as a manifestation of connective tissue dysplasia showed that women in the major group had additional visceral phenotypic markers of connective tissue dysplasia: mitral valve prolapsed was found in 38 $(31.7 \%)$ women $(p<0.05)$; atrial septal defect - in 4 (3 \%), joint hypermobility - $31(25.8 \%)(p<0.05)$, skin elastosis - in 56 (46.7\%) $(p<0.05)$.

Indeed, connective tissue dysplasia (CTD) is a consequence of organs and tissues developmental disorders in the fetal and in the postnatal periods. CTD reflects reduced levels of certain collagens or an imbalance between them leading to lesser strength in the connective tissue at large. Macroscopic features of CTD may reveal themselves as dysembryogenic stigmas varying from obvious teratism to nearly invisible signs [6]. 
The small pelvis vein disease in women is a disease associated with non-differentiated forms of connective tissue dysplasia, the phenotypic markers of which have been found in $88 \%$ of adolescent girls, in $66 \%$ women in their reproductive period, in $70.2 \%$ of pregnant women, in $53.5 \%$ of women in their premenopausal and postmenopausal period. The cases of the small pelvis vein disease in adolescent girls as well as in pregnant women showed markers of connective tissue metabolic disturbance, which correlated with mild dysplastic process profiles - increased sialic acids serum levels and prevalent excretion of free oxyproline and glycosaminoglycans [8].

In the current research women of the main group showed a significantly higher rate of pregnancy complications typical of CTD. The threat of spontaneous abortion was detected at various gestational ages in $120(100 \%)(p<0.01)$ of cases, while in $25(20.8 \%)$ women ultrasound data helped identify istmicocervical insufficiency, which in 6 $(5 \%)$ cases required a ligature on the uterine cervix, and in another $19(15 \%)(p<0.05)$ of cases took a retentive pessary device.

Late pregnancy gestosis was the basis for complicated pregnancy in $63(52.5 \%)$ women of the main group $(p<0.05)$. These complications served the risk factors of coagulopathic disorders in the postpartum period, and even more required timely detection of postpartum vaginal and perineal hematomas or fault hemostasis in the area of episiotomy stitches or soft tissue ruptures suturing in the birth canal.

Chronic placental insufficiency was diagnosed in $75(62.5 \%) \quad(p<0.05)$ women in the main groups; notable here is the prevalence in 50 cases (accounting for $41.7 \%$ ) of fetoplacental insufficiency (SDR a. umb. 3.31 \pm 0.02 ). Russian research findings, too, offer data pointing at the fact that impaired uteroplacental perfusion is more frequent in case of the small pelvis vein disease ( $41.7 \%$ of women), while in case of varicose veins of the lower extremities this index is $10.8 \%$. Disturbed uterofetoplacental hemodynamics is detected only in $3.3 \%$ of pregnant women suffering from the small pelvis vein disease [4].

The number of big fetuses correlated highly between the two groups.

An analysis of the labor process showed a significant increase in the frequency of labor anomalies in the main group: uterine inertia was found in $28(23.3 \%)$ women $(p<0.05)$, oxytocia - in $18(15 \%)$ women $(\mathrm{p}<0.05)$, accelerated labor - in $8(6.7 \%)$ women.

Of special interest is labor traumatism here. For instance, various degrees of clytroclasia were found in $35(29 \%)$ of the women $(p<0.05)$, Ist Degree perineal rupture - in $24(20 \%)(p<0.05)$ women. There was a thorough surgical hemostasis conducted with ligature exploration when transferring the women into the maternal child unit, which was done together with a dynamic assessment of potential hematomas clinical manifestations.
Yet, an ultrasound study held 2 hours after the delivery showed vaginal hematomas in $31(25.8 \%)$ women while only $10(8 \%)$ women had vaginal mucous membrane defects, and 21 (17\%) women had no such defects. In no case the women revealed any complaint typical of hematomas development.

It is to be noted that the ultrasound diameter of hematomas was $10.1 \pm 3.6 \mathrm{~cm}$ (5 to $15 \mathrm{~cm}$ ). This was demonstration to the fact that vaginal hematomas with a maximum diameter of up to $15 \mathrm{~cm}$ in the early postpartum period may be asymptomatic. The risk of massive blood loss comes up when such women are transferred to the maternal child unit with no timely diagnostics of postpartum vaginal and perineal hematomas or fault hemostasis in the area of episiotomy stitches or tissue ruptures suturing in the birth canal, especially in the event of coagulopathic disorders resulting from preeclampsia, premature detachment of normally positioned placenta, hereditary defect of hemostasis, etc. An asymptomatic postpartum vaginal hematoma may be the reason for an underestimated total blood loss in women with postpartum hemorrhage, which is due to contractive activity of the uterus, retention of secundines in the uterine cavity, coagulopathic bleeding, hysterocervicorrhexis, etc. This risk is especially high in case of labor analgesia, using narcosis to explore the uterine cavity, and tissue ruptures suturing in the birth canal.

This makes especially urgent the need to take into account that even in case of adequate surgical hemostasis a hematoma relapse is not impossible, especially when we are talking about women suffering from non-differentiated connective tissue dysplasia.

Conclusion. Women suffering from nondifferentiated connective tissue dysplasia show a higher risk of postpartum hematomas development. Asymptomatic development of a postpartum vaginal hematoma my result in underestimated total blood loss in women with postpartum hemorrhage, which is due to various equally meaningful reasons. The use of analgesia in labor hinders timely diagnosis of postpartum hematomas of vagina, perineum or defects in hemostasis in the area of episiotomy stitches or suturing soft tissue ruptures of the birth canal.

A transperineal ultrasound study in the postpartum period allows timely detection of vaginal hematomas. Women with varicose veins reveal a higher risk of vaginal hematomas with no vaginal mucous membrane defects, which comes as an effect of connective tissue dysplasia. While viewing vein disease as a visceral phenotypic marker of non-differentiated connective tissue dysplasia, in women with clinical presentations of connective tissue dysplasia, both differentiated and non-differentiated, it is important that transperineal ultrasound study be done in early postpartum period thus preventing acute massive blood loss in the postpartum period through timely detection of potential vaginal hematomas. 


\section{References}

1. Aylamazyan E. K., Kulakov V. I., Radzinskiy V. E., Savelyeva G. M. Obstetrics: National Guide. M.: «GEOTAR - Media»; 2007. $1200 \mathrm{p}$.

2. Obstetrics and gynecology. Differential diagnostics from A to Z / Ed. Tony Hollingworth. M.: «GEOTAR - Media»; 2010. $400 \mathrm{p}$

3. Artyimuk N. V. Varicose veins of the small pelvis in women. Russian journal of obstetrician-gynecologist. 2007;6:74-77.

4. Babadzhanova G. S., Habibullaeva M. F. Diagnostics and treatment of small pelvis vein disease in pregnant women. Woman's health. 2009;4(40):28-30.

5. Bogachev V. Yu. Small pelvis vein disease. Consilium medicum. 2006;1(1):20-23.

6. Ilyina I. Yu. Varicose veins of the small pelvis in women as a manifestation of connective tissue dysplasia. Russian journal of obstetrician-gynecologist. 2009;2:39-42.

\author{
RISK OF MASSIVE BLOOD LOSS \\ IN POSTPARTUM VAGINAL HEMATOMA \\ NOVIKOVA V. A., ASEEVA E. V. \\ UGLOVA N. D., KHOROLSKY V. A., \\ FILINA K. V., KAZIBEKOVA F. S.
}

Bleeding in the postpartum period poses a threat to the woman's life. Vaginal hematomas of $10.1 \pm 3.6 \mathrm{~cm}$ in the size can be asymptomatic at the onset, which may cause underestimation of the total blood loss in women with postpartum hemorrhage due to a variety of other competing causes. The use of analgesia in labor hinders timely diagnosis of postpartum hematomas of vagina, perineum or defects in hemostasis in the area of episiotomy stitches or suturing of soft tissue ruptures in the birth canal. The present study investigated 120 women with varicose veins of the lower extremities, their median age being 24.2 \pm 5.12 , the gestational age at delivery - 38.20 \pm 1.09 weeks. In order to timely diagnose postpartum hematomas in the vagina, the perineum or hemostasis defects in the area of episiotomy stitches or suturing of soft tissue ruptures in the birth canal, 2 hours after the labor women underwent transperineal ultrasound study of the vagina (Ultrasound Scanner PHILLIPS HD-11). Vaginal hematomas were detected in 31 $(25.8 \%)$ women, and only 10 (8\%) women had damage to the mucous layer of the vaginal wall, while in $21(17 \%)$ women this was not the case. None of the women revealed any complaint typical of patients with hematomas.

Key words: postpartum hemorrhage, massive blood loss, vaginal hematoma
7. Clinical recommendations. Obstetrics and Gynecology. $-4^{\text {th }}$ edition, revised / Ed. V.N. Serov, G.T. Sukhikh. M.: «GEOTAR - Media»; 2014. P. 499-514.

8. Mozes V. G. Varicose veins of the small pelvis in women through various life stages: Abstract, Thesis of Cand. of Med. Sc. Tomsk; 2006. 39 p.

9. Sukhikh G. T., Serov V. N., Savelieva G. M. et al. Prevention and therapy of massive blood loss in obstetrics. Medical technology FS№ 2010/141, of 29/04/2010.

10. Daliakopoulos S. Gigantic retroperitoneal hematoma as a complication of anticoagulation therapy with heparin in therapeutic doses: a case report. Journal of Medical Case Reports. 2008;2:162

11. WHO recommendations for prevention and treatment of postpartum hemorrage, 2012.

\section{РИСК МАССИВНОЙ КРОВОПОТЕРИ ПРИ ПОСАЕРОАОВЫХ ГЕМАТОМАХ ВААГААИЩА}

B. А. НОВИКОВА, Е. В. АСЕЕВА, Н. А. УГАОВА,

В. А. ХОРОАЬСКИЙ, К. В. ФИАИНА,

Ф. Ш. КАЗИБЕКОВА

Кровотечение в послеродовом периоде представляет угрозу для жизни женщины. Гема-

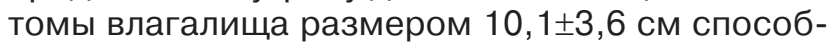
ны в начале формирования быть бессимптомными, что может явиться причиной недооценки общей кровопотери у женщин с послеродовым кровотечением вследствие других конкурирующих причин. Применение обезболивания родов затрудняет своевременную диагностику послеродовых гематом влагалища, промежности или дефектов гемостаза в зоне наложения швов после эпизиотомии или ушивания разрывов мягких тканей родовых путей. В настоящем исследовании обследовано 120 женщин с варикозной болезнью вен нижних конечностей, средний возраст 24.2 25.12 лет, срок беременности при

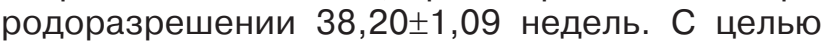
своевременной диагностика послеродовых гематом влагалища, промежности или дефектов гемостаза в зоне наложения швов после эпизиотомии или ушивания разрывов мягких тканей родовых путей через 2 часа после родов женщинам проводилось трансперинеальное УЗ- исследование влагалища, промежности на ультразвуковом сканере PHILLIPS HD-11. Гематома влагалища определена у 31 (25,8 \%) женщины и только у 10 (8 \%) отмечалось нарушение целостности слизистой оболочки, у 21 (17\%) нарушения целостности слизистой влагалища не было. Ни в одном случае женщина не предъявляла характерных для формирования гематом жалоб.

Ключевые слова: послеродовое кровотечение, массивная кровопотеря, гематомы влагалища 